\title{
Study of the Electrochemical Deposition of Cu/Sn Alloy Nanoparticles on Boron Doped Diamond Films for Electrocatalytic Nitrate Reduction
}

Jorge T. Matsushima, Andrea B. Couto, Neidenei G. Ferreira and Mauricio R. Baldan

LABEMAC / INPE, 12245-970, São Jose dos Campos, SP, Brazil.

\begin{abstract}
This paper presents the study of the electrochemical deposition of $\mathrm{Cu} / \mathrm{Sn}$ alloy nanoparticles on Boron Doped Diamond (BDD) films in order to improve their electrocatalytic activity and selectivity for application in nitrate electrochemical reduction. Cyclic voltammetry measurements evidenced the formation of $\mathrm{Cu} / \mathrm{Sn}$ alloy electrodeposited on BDD electrode. The electrodeposited $\mathrm{Cu} / \mathrm{Sn}$ can be better visualized by analyzing the dissolution process. By studying the dissolution peak separately, the dissolution peak of the Sn was obtained at a more positive potential, when compared with the dissolution peak of $\mathrm{Cu}$. From the scanning electronic microscopy (SEM) analysis, the homogeneous distribution of the $\mathrm{Cu} / \mathrm{Sn}$ alloys particles on BDD surface with grain size in nanometric scale was verified. From X-ray diffraction analysis, two $\mathrm{Cu} / \mathrm{Sn}$ alloy phases $\left(\mathrm{Cu}_{41} \mathrm{Sn}_{11}\right.$ and $\left.\mathrm{Cu}_{10} \mathrm{Sn}_{3}\right)$ were identified for the electrodeposits obtained at $0.5 \mathrm{~V}$ and charge of $0.26 \mathrm{C}$. The electrocatalytic reduction of nitrate in $0.1 \mathrm{M}$ Britton-Robinson (BR) buffer solution with $\mathrm{pH} 9$ was analyzed. The BDD electrode modified with $\mathrm{Cu} / \mathrm{Sn}$ alloy nanoparticles proved to potentiate the electrocatalytic reduction of nitrate.
\end{abstract}

\section{INTRODUCTION}

Nowadays, electrode materials based on boron doped diamond (BDD) films is available in a variety of forms and at different levels of doping, resulting in films with unique properties. Among the numerous areas of electrochemistry, BDD electrodes have been applied in electroanalysis [1] and also used for waste water treatment [2,3]. Concerning these applications, some reports have shown their use in electroanalysis and in the removal of nitrate [4-7]. The presence of excessive nitrate in water, particularly, due to the use of nitrogen-based fertilizers, may cause danger to the environment and also to human health [8]. In this respect, the control of this species in biosphere has received a great deal of attention, including the development of more efficient methodologies for its detection and its removal from water bodies and from waste water. Electrochemical methods have received special attention, due to the use of clean reagents (i.e, electrons) for such purposes. Recently, the surface modification with metallic nanoparticles or clusters has been widely used as an advantageous procedure to improve the electrocatalytic and the electroanalytical ability of electrode materials $[9,10]$. This procedure is known to have a number of attributes that make it highly appealing for different applications, especially for the use in electroanalysis. At the nanoscale, electrode materials may exhibit certain properties otherwise unobserved in the bulk or macro material, such as: a higher surface area, an improved catalytic activity and an enhanced diffusion process based on convergent rather than linear diffusion at smaller [11-13].To improve the selectivity and sensitivity of BDD electrode, the electrochemical deposition of $\mathrm{Cu} / \mathrm{Sn}$ alloy nanoparticles on its surface is a possible procedure for increasing its diversity and application for analyzing nitrate. First, as previously discussed, it is known that modified electrodes with metallic nanoparticles may exhibit certain properties otherwise unobserved in the bulk or macro electrode. Also, the $\mathrm{Cu}$ is the coinage metal to be the 
most active surface electrocatalyst concerning the rate of the nitrate reduction, but the main byproducts obtained in this reaction, such as nitrite and ammonia are more toxic than nitrate [14]. However, the main drawback to the use of a $\mathrm{Cu}$ modified BDD is the surface instability of the nanoparticles due to their tendency to corrode. One way to solve these drawbacks may be achieved from the deposition of a $\mathrm{Cu}$ alloy. Particularly, the surface modification from the electrodeposition of a $\mathrm{Cu} / \mathrm{Sn}$ alloy is associated with their attractive features, especially, its resistance to corrosion. The use of the $\mathrm{Sn}$ for obtaining $\mathrm{Cu} / \mathrm{Sn}$ alloy nanoparticles is also associated to the synergetic effect for the electrocatalytic nitrate reduction, since it is another known promoter for such application $[15,16]$.

\section{EXPERIMENTAL}

The electrochemical deposition of the $\mathrm{Cu} / \mathrm{Sn}$ alloy was studied on BDD grown on silicon substrate by Hot Filament Chemical Vapor Deposition (HTCVD) technique at $780^{\circ} \mathrm{C}$ for $7 \mathrm{~h}$. A gaseous mixture $\left(99 \%\right.$ vol. $\mathrm{H}_{2}$ and $1 \%$ vol. $\left.\mathrm{CH}_{4}\right)$ with a total pressure of 50 Torr was used. The boron doping was obtained from $\mathrm{H}_{2}$ forced to pass through a bubbler containing $\mathrm{B}_{2} \mathrm{O}_{3}$ dissolved in methanol with a controlled B/C ratio. From the Mott Schottky plot, the doping level was estimated to approximately $10^{20} \mathrm{~B}$ atoms cm $\mathrm{cm}^{-3}$ [17]. The electrochemical measurements were made using the Autolab PGSTAT 302 equipment with a three-electrode cell. The BDD films were used as a working electrode and the geometric area in contact with the electrolyte was 0.27 $\mathrm{cm}^{2}$. A platinum coil wire served as a counter electrode and the $\mathrm{Ag} / \mathrm{AgCl}$ electrode was used as a reference electrode. The electrodeposition process of the $\mathrm{Cu} / \mathrm{Sn}$ alloy on BDD was investigated by cyclic voltammetry (CV) using a solution containing $10 \mathrm{mM} \mathrm{Cu(II)}$ ions $+10 \mathrm{mM} \mathrm{Sn}$ (II) ions $+0.5 \mathrm{M} \mathrm{H}_{2} \mathrm{SO}_{4}$ and its electrochemical response was compared to those obtained for the pure system of $\mathrm{Cu}$ and $\mathrm{Sn}$ using solutions containing $0.5 \mathrm{M} \mathrm{H}_{2} \mathrm{SO}_{4}$ with $10 \mathrm{mM} \mathrm{Cu}$ (II) ions and 10 $\mathrm{mM} \mathrm{Sn}(\mathrm{II})$ ions, respectively. To evaluate the electrocatalytic reduction of nitrate, the $\mathrm{Cu} / \mathrm{Sn}$ alloy nanoparticles modified BDD electrode was prepared using potentiostatic mode by applying $-0.9 \mathrm{~V}$ for $10 \mathrm{~s}$. The morphology of the $\mathrm{Cu} / \mathrm{Sn}$ alloy modified BDD electrode was analyzed by scanning electronic microscopy (SEM) using a Jeol equipment JSM-5310 and the X-ray diffraction (XRD) patterns were produced to characterize the $\mathrm{Cu} / \mathrm{Sn}$ alloy phases electrodeposited on the BDD surface using a PANalytical model X'Pert Powder diffractometer with the $\operatorname{CuK} \alpha(\lambda=1.54 \AA)$, set at $45 \mathrm{kV}$ and $25 \mathrm{~mA}$, running in the $\omega / 2 \theta$ scanning mode with $\omega$ $=1^{\circ}$ and $2 \theta=10$ to $100^{\circ}$. The $\mathrm{Cu} / \mathrm{Sn}$ alloy phases electrodeposited were identified using X'Pert High Score report of the PANalytical. The electrochemical reduction of nitrate was tested by linear sweep voltammetry (LSV) using $0.1 \mathrm{M} \mathrm{KNO}_{3}+0.1 \mathrm{M}$ Britton Robinson (BR) buffer solution with $\mathrm{pH} 9$.

\section{RESULTS AND DISCUSSION}

To evaluate the formation of a $\mathrm{Cu} / \mathrm{Sn}$ alloy system electrochemically deposited on the BDD electrode, the $\mathrm{CV}$ measurements were carried out using separate $\mathrm{Cu}$ (II) and $\mathrm{Sn}$ (II) ions solutions and the electrochemical behavior was compared to those obtained in a mixed $\mathrm{Cu}(\mathrm{II})$ $\mathrm{Sn}$ (II) ions solution. The cyclic voltammograms obtained in these conditions are illustrated in Figure 1. By sweeping the potential, the onset of the $\mathrm{Cu}$ (II) ions to metallic $\mathrm{Cu}$ reduction occurs at $-0.1 \mathrm{~V}$ (curve (a)). The onset of $\mathrm{Sn}(\mathrm{II})$ ions to metallic $\mathrm{Sn}$ reduction was verified to occur at $0.3 \mathrm{~V}$ a more negative potential when compared with the onset of the $\mathrm{Cu}(\mathrm{II})$ ions to metallic $\mathrm{Cu}$ 
(curve (b)). Based on the standard electrode potential values in aqueous solutions, the $\mathrm{Cu}(\mathrm{II})$ ions reduction is more favorable, which justify this behavior. However, the solution composition, due to the presence of both metal ions, thermodynamically, favored the codeposition of the two metals, resulting in the $\mathrm{Cu} / \mathrm{Sn}$ alloy deposition (curve (c)), which started in a potential value located between the onset of the deposition of the metallic $\mathrm{Sn}$ and $\mathrm{Cu}$.

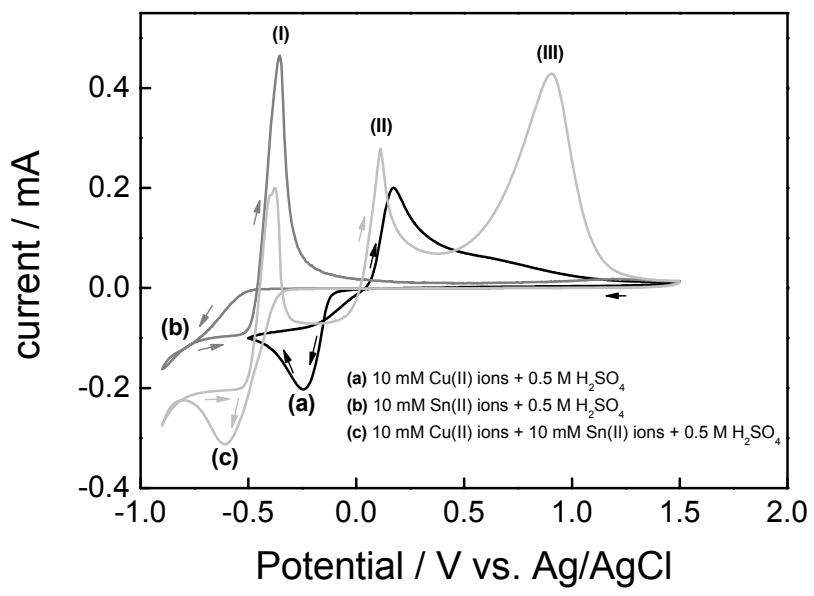

Figure1. Voltammetric curves for BDD substrate in solutions containing $10 \mathrm{mM} \mathrm{Cu}(\mathrm{II})$ ions (curve(a)), $10 \mathrm{mM} \mathrm{Sn(II)} \mathrm{ions} \mathrm{(curve} \mathrm{(b))} \mathrm{and} 10 \mathrm{mM} \mathrm{Cu(II)} \mathrm{ions} \mathrm{+} 10 \mathrm{mM} \mathrm{Sn}$ (II) ions (curve (c)). All solutions containing $0.5 \mathrm{M} \mathrm{H}_{2} \mathrm{SO}_{4}$ as supporting electrolyte. Scan rate of $10 \mathrm{mV} \mathrm{s}^{-1}$.

During the alloy deposition, a higher cathodic current was involved when compared to the deposition process of the pure $\mathrm{Sn}$ or $\mathrm{Cu}$. A cathodic current peak at $-0.6 \mathrm{~V}$ was observed. From this potential, a current decrease was verified, indicating the onset of the $\mathrm{Cu} / \mathrm{Sn}$ alloy deposition process being controlled by diffusion. Approximately at $-0.8 \mathrm{~V}$, the current again increased, due to the hydrogen evolution reaction. By reversing the potential sweep to positive values was observed the dissolution processes of the pure $\mathrm{Cu}$ (curve (a)), Sn (curve (b)) and the $\mathrm{Cu} / \mathrm{Sn}$ alloy (curve (c)). The stripping process of the pure $\mathrm{Sn}$ started at $-0.46 \mathrm{~V}$ and resulted in a well defined current peak located at $-0.36 \mathrm{~V}$, which is associated to oxidation of the metallic $\mathrm{Sn}$ to $\mathrm{Sn}(\mathrm{II})$ ions. By analyzing the pure $\mathrm{Cu}$ dissolution, two anodic current regions are observed, a well-defined anodic current peak located at a more negative potential which is associated with the bulk $\mathrm{Cu}$ stripping (metallic $\mathrm{Cu}$ to $\mathrm{Cu}$ (II) ions oxidation) followed by a large potential region, with the formation of a current shoulder at $0.32 \mathrm{~V}$, which may be due to the stripping of the other deposited $\mathrm{Cu}$ phase. Regarding the $\mathrm{Cu} / \mathrm{Sn}$ system dissolution, three anodic processes are observed. Process I is associated to the stripping of a Sn phase, since it begins at a same potential region of the corresponding Sn dissolution. In process II, a potential shift to a more negative value is verified, which probably occurred due to the dissolution of a $\mathrm{Cu} / \mathrm{Sn}$ phase rich in $\mathrm{Cu}$ content, which was formed after the $\mathrm{Sn}$ re-deposition caused by the synergetic effect of the $\mathrm{Cu}$ that has not been dissolved by sweeping the potential for more positive values. By comparing the pure $\mathrm{Sn}$ (curve (b)) and $\mathrm{Cu}$ (curve (a)) stripping with respect to the $\mathrm{Cu} / \mathrm{Sn}$ system stripping (curve (c)) it is possible to confirm the deposition of a second $\mathrm{Cu} / \mathrm{Sn}$ phase (process III) formed during the negative potential sweep, where a intense anodic current peak is located at a more positive potential, indicating that the dissolution is more difficult due to the nobler behavior of the $\mathrm{Cu} / \mathrm{Sn}$ alloy bulk phase formed. 
From the electrochemical studies of the $\mathrm{Cu} / \mathrm{Sn}$ system, in which the formation of a $\mathrm{Cu} / \mathrm{Sn}$ alloy bulk phase on the BDD substrate was characterized, the electrocatalytic activity of the $\mathrm{Cu} / \mathrm{Sn}$ alloy nanoparticles modified BDD electrode for the electrochemical reduction of nitrate was evaluated. The $\mathrm{Cu} / \mathrm{Sn}$ alloy electrodeposition was made using $10 \mathrm{mM} \mathrm{Cu}$ (II) ions $+10 \mathrm{mM}$ $\mathrm{Sn}(\mathrm{II})$ ions $+0.5 \mathrm{M} \mathrm{H}_{2} \mathrm{SO}_{4}$ solution. The morphological and structural characterization of the $\mathrm{Cu} / \mathrm{Sn}$ alloy nanoparticles modified BDD electrode was performed by SEM and XRD analysis, respectively.
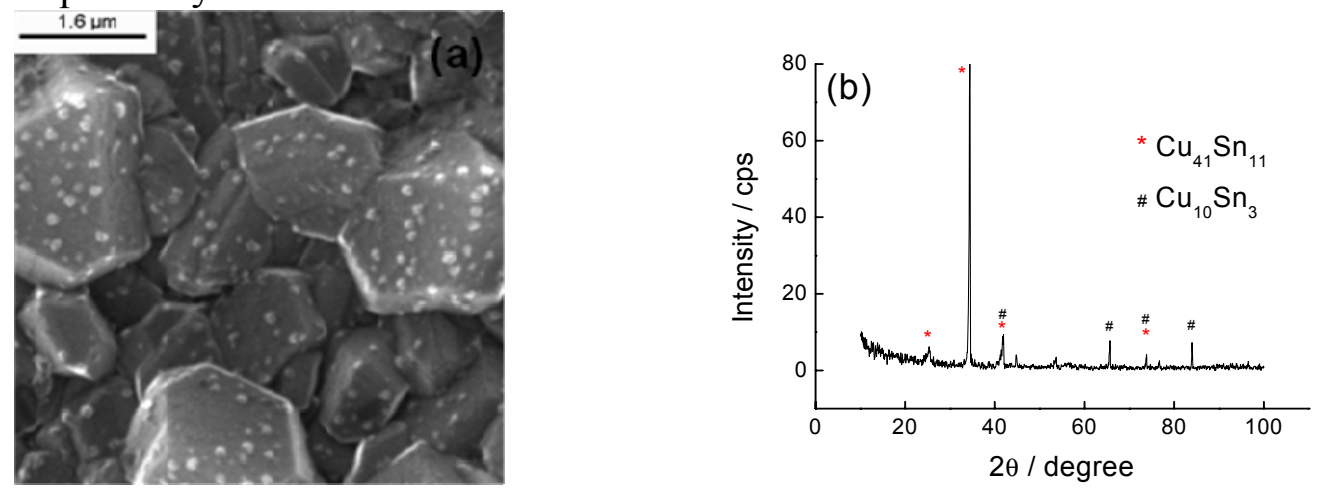

Figure 2. (a) SEM image of the $\mathrm{Cu} / \mathrm{Sn}$ alloy nanoparticles electrodeposited on BDD electrode and (b) XRD patterns for $\mathrm{Cu} / \mathrm{Sn}$ coating electrodeposited on BDD substrate under potentiostatic mode at $-0.5 \mathrm{~V}$ and resulting charge of $0.26 \mathrm{C}$. The $\mathrm{Cu} / \mathrm{Sn}$ alloy phases electrodeposited were identified using X'Pert HighScore report of the PANalytical.

Figure 2a shows the SEM image of the $\mathrm{Cu} / \mathrm{Sn}$ alloy nanoparticles electrodeposited on the BDD electrode obtained by potentiostatic mode at a deposition potential of $-0.5 \mathrm{~V}$ for $10 \mathrm{~s}$. Despite the polycrystalline structure of the BDD film, which may also be seen in Figure $2 \mathrm{a}$, it is possible to observe the deposition of $\mathrm{Cu} / \mathrm{Sn}$ alloy nanoparticles distributed with nanometric dimensions throughout the surface of the BDD electrode. The formation of the $\mathrm{Cu} / \mathrm{Sn}$ alloy phases was confirmed by analyzing the electrodeposit from the XRD analysis, as shown from the $\mathrm{XRD}$ patterns of the $\mathrm{Cu} / \mathrm{Sn}$ coating presented in Figure $2 \mathrm{~b}$. Figure $2 \mathrm{~b}$ shows XRD patterns of the $\mathrm{Cu} / \mathrm{Sn}$ coating electrodeposited on the BDD substrate. The $\mathrm{Cu} / \mathrm{Sn}$ alloys phases were identified from the X'Pert HighScore software of the PANalytical from the XRD experiment done using the $\omega / 2 \theta$ scanning mode, running $2 \theta$ from 10 to $100^{\circ}$ (fixing $\omega=1^{\circ}$ ). From the XRD patterns, two phases $\left(\mathrm{Cu}_{41} \mathrm{Sn}_{11}\right.$ and $\left.\mathrm{Cu}_{10} \mathrm{Sn}_{3}\right)$ for $\mathrm{Cu} / \mathrm{Sn}$ alloy electrodeposits were identified. This result confirms the one already discussed in the study involving the reversing of the potential sweep at different values in deposition region of the $\mathrm{Cu} / \mathrm{Sn}$ alloy (not shown in this paper), in which at a less negative potential sweep was verified only the electrodeposition of the $\mathrm{Cu} / \mathrm{Sn}$ alloy phase rich in $\mathrm{Cu}$ content and the $\mathrm{Cu} / \mathrm{Sn}$ alloy bulk phase. From the correlation of these results with the one that was obtained from the CV measurements presented in Figure1, it is believed that the deposition of the $\mathrm{Cu} / \mathrm{Sn}$ alloy phase rich in $\mathrm{Cu}$ content is one associated to $\mathrm{Cu}_{41} \mathrm{Sn}_{11}$ phase due to the dissolution of the $\mathrm{Cu} / \mathrm{Sn}$ alloy phase rich in $\mathrm{Cu}$ content (process II) which occurred at a potential close to pure $\mathrm{Cu}$ dissolution.

The electrochemical reduction of nitrate was tested using $0.1 \mathrm{M} \mathrm{KNO}_{3}+0.1 \mathrm{M} \mathrm{BR}$ buffer solutions at extreme $\mathrm{pH}$ values ( $\mathrm{pH} 1.9$ and 9.0). In our first experiments, the best condition for analyzing the nitrate response was obtained by using $0.1 \mathrm{M}$ BR buffer solution with $\mathrm{pH} 9$. Moreover, a higher chemical stability for electrodeposited $\mathrm{Cu} / \mathrm{Sn}$ alloy was verified in alkaline media. A similar condition was also achieved by other authors in their studies about $\mathrm{Cu} / \mathrm{Pd}$ alloy 
modified Pt and Ni electrodes [18,19]. Although there are less detailed mechanism studies of nitrate reduction in alkaline media compared with acidic media, there seen to be some important difference with the behavior in acidic media. Part of the reason for this is the fact that some potential electrode materials for nitrate reduction are stable in alkaline media whereas they are unstable in acidic media. Moreover, some patents based on nitrate electrolysis show interesting aspects in removing nitrate from low-level alkaline nuclear waste (for an introduction into this kind of application see the paper by Bockris and Kim [20]).

Figure 3 presents the LSV curves of the unmodified BDD electrode and also of the $\mathrm{Cu} / \mathrm{Sn}$ alloy modified BDD electrode obtained in $0.1 \mathrm{M} \mathrm{BR}$ buffer solution $\mathrm{pH} 9$ with and without nitrate addition. The sweep range from $-0.4 \mathrm{~V}$ to $-1.2 \mathrm{~V}$ was defined considering the potential region where no reactions involving the $\mathrm{Cu} / \mathrm{Sn}$ occur. From the electrochemical response of the unmodified BDD electrode without nitrate addition it was possible to verify only the cathodic current increase associated to water decomposition reaction occurring at approximately $-1.1 \mathrm{~V}$, with a maximum cathodic current of $5 \mu \mathrm{A}$ at $-1.2 \mathrm{~V}$. This low cathodic current at $-1.2 \mathrm{~V}$ is associated to large cathodic potential window for water decomposition reaction. This peculiar characteristic of the BDD electrode makes it an excellent material to be used as electrode material without the interference of this reaction on the nitrate reduction, which may directly decrease the current efficiency for occurring the nitrate reduction.

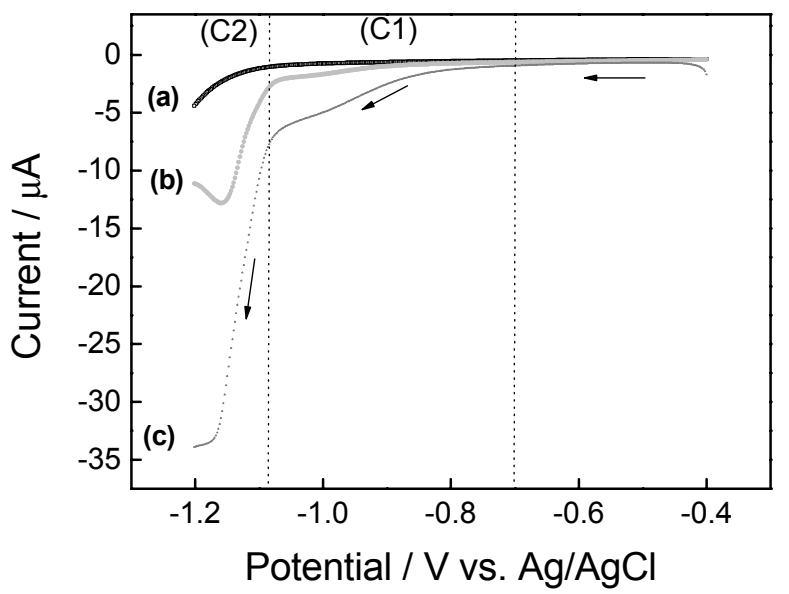

Figure 3. LSV curves obtained in $0.1 \mathrm{M}$ BR buffer solution with $\mathrm{pH} 9$ (a) for the unmodified BDD electrode without nitrate addition, (b) for the unmodified BDD with nitrate and (c) for the $\mathrm{Cu} / \mathrm{Sn}$ alloy nanoparticles electrodeposited on BDD electrode in BR with nitrate addition. Scan rate of $10 \mathrm{mV} \mathrm{s}^{-1}$.

By adding $0.1 \mathrm{M} \mathrm{KNO}_{3}$ in $0.1 \mathrm{M}$ BR buffer solution with $\mathrm{pH} 9$, two cathodic processes regarding the nitrate reduction were observed. The $\mathrm{C} 1$ process located at a more positive potential may be due to the occurrence of the nitrate reduction with the production of nitrite ions followed by nitrate or nitrite reduction to ammonia ( $\mathrm{C} 2$ process). The advantage of using the $\mathrm{Cu} / \mathrm{Sn}$ alloy modified BDD electrode on the nitrate reduction was verified. In this case, a significant increase of cathodic current with respect to the $\mathrm{C} 1$ and $\mathrm{C} 2$ processes was observed. In particular, the involved cathodic current in nitrate or nitrite reduction to ammonia (C2 process) increased roughly by 3 times compared to unmodified BDD electrode. Thus, these results, high electrocatalytic activity of the $\mathrm{Cu} / \mathrm{Sn}$ alloy modified BDD electrode was demonstrated, which enables its application as promising material for the electroanalysis and/or for the removal of nitrate. 


\section{CONCLUSIONS}

The formation of a $\mathrm{Cu} / \mathrm{Sn}$ alloy on the BDD electrode by electrodeposition was demonstrated by comparing the electrochemical behavior using separate $\mathrm{Cu}$ (II) ions and $\mathrm{Sn}$ (II) ions solutions and mixed $\mathrm{Cu}(\mathrm{II})-\mathrm{Sn}$ (II) ions solutions. From these studies, three metallic phases were obtained: the pure $\mathrm{Sn}$ phase, the $\mathrm{Cu} / \mathrm{Sn}$ alloy phase rich in $\mathrm{Cu}$ content and, the $\mathrm{Cu} / \mathrm{Sn}$ alloy bulk phase. From the SEM analysis the homogeneous distribution of the $\mathrm{Cu} / \mathrm{Sn}$ alloy particles on $\mathrm{BDD}$ surface with grain size in nanometric scale was verified. From $\mathrm{XRD}$ analysis, two $\mathrm{Cu} / \mathrm{Sn}$ alloy phases $\left(\mathrm{Cu}_{41} \mathrm{Sn}_{11}\right.$ and $\left.\mathrm{Cu}_{10} \mathrm{Sn}_{3}\right)$ for the electrodeposits obtained at $-0.5 \mathrm{~V}$ and charge of $0.26 \mathrm{C}$ were identified. The electrocatalytic reduction of nitrate analyzed in $0.1 \mathrm{M} \mathrm{BR}$ buffer solution with $\mathrm{pH} 9$ using the $\mathrm{Cu} / \mathrm{Sn}$ alloy nanoparticles modified BDD electrode has proved to be promising due to the significant increase regarding the involved current for nitrate reduction compared to the unmodified BDD electrode.

\section{ACKNOWLEDGMENTS}

The authors thank the Brazilian research funding institutions, CAPES and FAPESP.

\section{REFERENCES}

1. R. Tenne, K. Patel, K. Hashimoto and A. Fujishima, J. Electroanal. Chem. 347, 409 (1993).

2. M. Panizza, E. Brillas and C. Comninellis, J. Environ. Eng. Management 18, 139 (2008).

3. V. Schmalz, T. Dittmar, D. Haaken and E. Worch, Water Res. 43, 5260 (2009).

4. C. Levy-Clement, N. A. Ndao, A. Katty, M. Bernard, A. Deneuville, C. Comninellis and A. Fujishima, Diam. Relat. Mater. 12, 606 (2003).

5. F. Bouamrane, A. Tadjeddine, J. E. Butler, R. Tenne and C. Levy-Clement, J. Electroanal. Chem. 405, 95 (1996).

6. C. Reuben, E. Galun, H. Cohen, R. Tenne, R. Kalish, Y. Muraki, K. Hashimoto, A. Fujishima, J.M. Butler and C. Lévy-Clément, J. Electroanal. Chem. 396, 233 (1995).

7. R. Tenne, K. Patel, K. Hashimoto and A. Fujishima, J. Electroanal. Chem. 347, 409 (1993).

8. K. H. Gelberg, L. Church, G. Casey, M. London, D. S. Roerig, J. Boyd and M. Hill, Environ. Res. 80, 34 (1999).

9. F.W. Campbell and R.G. Compton, Anal. Bional. Chem. 396, 241 (2010).

10. G. Siné, I. Duo, B. El Roustom, G. Fóti and C. Comninellis, J. App. Electrochem. 36, 847 (2006).

11. C.M. Welch and R.G. Compton, Anal. Bioanal. Chem. 384, 601 (2006).

12. K.E. Toghill and R.G. Compton, Electroanalysis 22, 1947 (2010).

13. F.W. Campbell and R.G. Compton, Anal. Bioanal. Chem. 396, 241 (2010).

14. G.E. Dima, A.C.A. Vooys and M.T.M. Koper, J. Electroanal. Chem. 554, 15 (2003).

15. T. Ya Safanova and O.A. Petrii, Russ. J. Electrochem. 34, 1137 (2002).

16. K. Shimazu, R. Goto and K. Tada, Chem. Lett. 204 (2002).

17. N. G. Ferreira, L. L. G. Silva, E. J. Corat, V. J. Trava Airoldi and K. Iha, Braz. J. Phys. 29, 760 (1999).

18. C. Milhano, and D. Pletcher, J. Electroanal. Chem. 614, 24 (2008).

19. D. Reyter, D. Bélanger and L. Roué, J. Phys. Chem. C 113, 290 (2009).

20. J.O.M. Bockris and J. Kim, J. Appl. Electrochem. 27, 623 (1997). 